\title{
Stability of Road Earth Structures in the Complex And Complicated Ground Conditions
}

https://doi.org/10.2478/sgem-2018-0028

received October 18, 2018; accepted October 31, 2018.

Abstract: Some important modern problems of the transport engineering, which occur in the newly built and modernised road objects, have been indicated in the work. A discussion was conducted regarding the methods of assessing the stability of slopes of the road embankments, the obtained stability margins and the interpretation of obtained results in the specific cases of foundations of the road earth structures. Presented observations result from analysing the stability assessments of slopes of the road embankments, which was conducted on many communication objects, characterised by high variability of foundation conditions.

Keywords: slope stability; road embankments, transport engineering, soft soils.

\section{Introduction}

Foundations of the objects of land transport infrastructure constitute a significant problem in connection with the implemented constructions and modernisation of the network of roads and motorways. Earth structures are their inseparable element. Studies on carrying capacity, durability and sensitivity of roadway structure are conducted on a large scale. However, there are very often problems with the destruction of the surface structure resulting from failures of the road embankments. This is affected by many factors such as complex and complicated geological-engineering conditions of the substrate (low-strength substrates, landslide areas, glacitectonic disturbances, mining damages), improper selection of the embankment body material, improper performance and protection of the body, lack of monitoring, floods and influence of atmospheric factors.

\footnotetext{
*Corresponding author: Andrzej Batog, Elżbieta Stilger-Szydło, Wroctaw University of Science and Technology, Faculty of Civil Engineering, Wrocław, Poland, E-mail: Andrzej.Batog@pwr.edu.pl; Elzbieta.Stilger-Szydlo@pwr.edu.pl
}

There is a need for correct identification of the subsoil, design and performance of embankments with the use of appropriate methods for strengthening the substrate and securing the earth structure itself.

The stability problems of slopes of the road embankments, obtained stability margins and interpretation of obtained results in the specific cases of foundations of the road earth structures have been indicated in this work. Presented results and observations were obtained for the communication objects, characterised by high variability of foundation conditions.

\section{Stability Margins of Slopes and Embankments}

Many proposals of calculation methods for stability assessment are used in order to optimally design and predict the behaviour of embankment slopes and natural slopes.

In the group of theoretical methods of dimensioning slopes, based on the theory of plasticity, the methods of limit stress state and engineering methods of limit equilibrium are dominant. In a static context, the theory of limit states allows to determine relations between shape of the slope, limit load of the overburden and stress state in the whole massif. The kinematic method consists of searching for permitted fields of deformation velocity, which correspond to various flow mechanisms [7].

Methods of limit equilibrium are included in the fundamental analysis methods of slope stability, which are used in engineering practice. They assume the occurrence of a limit state on certain surfaces of the localised slip. By adopting a certain mechanism of deformation or destruction along the slip surface, the force system associated with this mechanism is analysed. The contemporary development of numerical methods (finite difference method [FDM], boundary element method [BEM] and, above all, finite element method [FEM]), as well as ground constitutive models, puts computational analyses at the forefront of research tools that are used 
to solve many geotechnical edge problems, including stability of slopes.

Despite many studies, there are no standard regulations and guidelines regarding the design of earth structures with foundations in complex and complicated geological engineering conditions. The recommendations contained in Eurocode 7 are only of general nature, and they do not take into account the specificity of the operation of earth structures in complex and complicated ground conditions or the specificity associated with differences in the operating conditions of particular types of earth structures (road, rail, hydro-technical structures, landfills, etc.). In the case of road embankments, a large number of unknowns, which are difficult to determine, result in the fact that there is no certainty in the scope of their stability.

In the previous article [1], the authors presented a detailed discussion concerning the principles of verifying the stability of road earth structures, which until recently were used in engineering practice, listing amongst others,

- assuming a certain probability of occurrence of the landslide as very unlikely $(F>1.5)$, unlikely $(1.3<F<$ $1.5)$, probable $(1.0<F<1.3)$ and very likely $(F<1.0)-$ [5], [12];

- provisions of the Regulations of the Minister of Transport and Maritime Economy [13], requiring the maintenance of a stability coefficient $F$ not lower than 1.5 (with the assumption of design load values and geotechnical parameters);

- provisions of Eurocode 7 in the scope of using the "strips" method [9].

Designing in accordance with Eurocode 7 requires a demonstration that the design action effects $E_{d}$ are not greater than the corresponding design resistance $R_{d}$ :

$$
R_{d}{ }^{3} E_{d} \text { or } \frac{R_{d}}{E_{d}} \geq 1
$$

Stability analysis leading to the determination of minimum value of the stability factor $F_{\min }$ should take into account the design values of geotechnical parameters, impacts and resistances obtained through the application of partial factors. In generally applied engineering methods of stability analysis (the so-called 'strips' methods), the rotating moment should be treated as a result of design actions $M_{E d}$ and the corresponding maintaining moment should be treated as design resistance in regard to these actions $M_{R d} M_{R}$. In the context of Eurocode 7, the stability factor defines the dependence

$$
F=\frac{M_{H}}{M_{B}}=\frac{\sum_{i=1}^{n} R_{d, i}}{\sum_{i=1}^{n}\left(W_{d, i}+Q_{d, i}\right) \sin \alpha_{i}} \geq 1
$$

where: $R_{e d, i}$ is the design shear resistance of ground along the base of the $i$ th block (strip), $\alpha_{i}$ is the angle of inclination of the base of the ith block to the horizontal level, $W_{d, i}$ is the design weight of the ith block, $Q_{d, i}$ is the external design load applied to the ith block.

In the case of this approach, the minimum stability factor should not be lower than 1. Condition (1) implies a diametrically different (from the traditionally applied) approach to the assessment of stability, in which the calculations were carried out by taking into account the characteristic values of ground impacts and reactions, whilst the required stability margin was achieved by assuming a sufficiently high acceptable value $F_{d o p}$.

Provisions of Eurocode 7 indirectly introduce the condition that it is not acceptable in the stability calculations to accept the lack of horizontal forces between the blocks. This excludes the application of popular Fellenius method, as well as a version of the Janbu method, in which only vertical reactions between blocks are considered [6] for the stability analysis. Owing to this limitation, the popular Bishop method (simplified) [4] is suitable for conducting engineering analyses of road slope stability, which fulfils the condition of balance of the moments of forces and projections of horizontal forces (figure 1). In this method, after the introduction of the relevant partial factors, the stability factor is described by the following generalised formula:

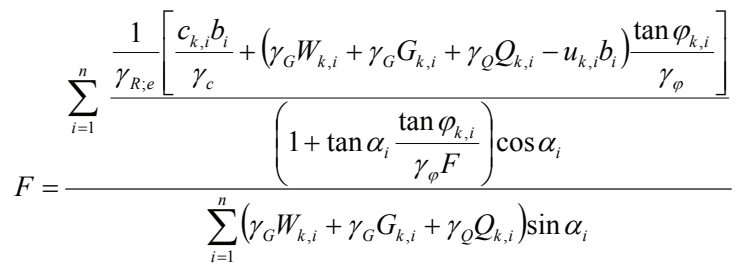

where: $c_{k, i}$ is the characteristic value of cohesion of the soil that can be found in the base of the ith block, $\varphi_{k, i}$ is the characteristic value of the angle of internal friction of the soil that can be found in the base of the ith block, $b_{i}$ is the width of the ith block, $\alpha_{i}$ is the angle of inclination of the base of the ith block in regard to the horizontal level, $W_{k, i}$ is the characteristic value of the weight of the ith block, $G_{k, i}$ is the characteristic value of the permanent load having impact on the $i$ th block, $Q_{k, i}$ is the characteristic value of the variable load having impact on the $i$ th block. 


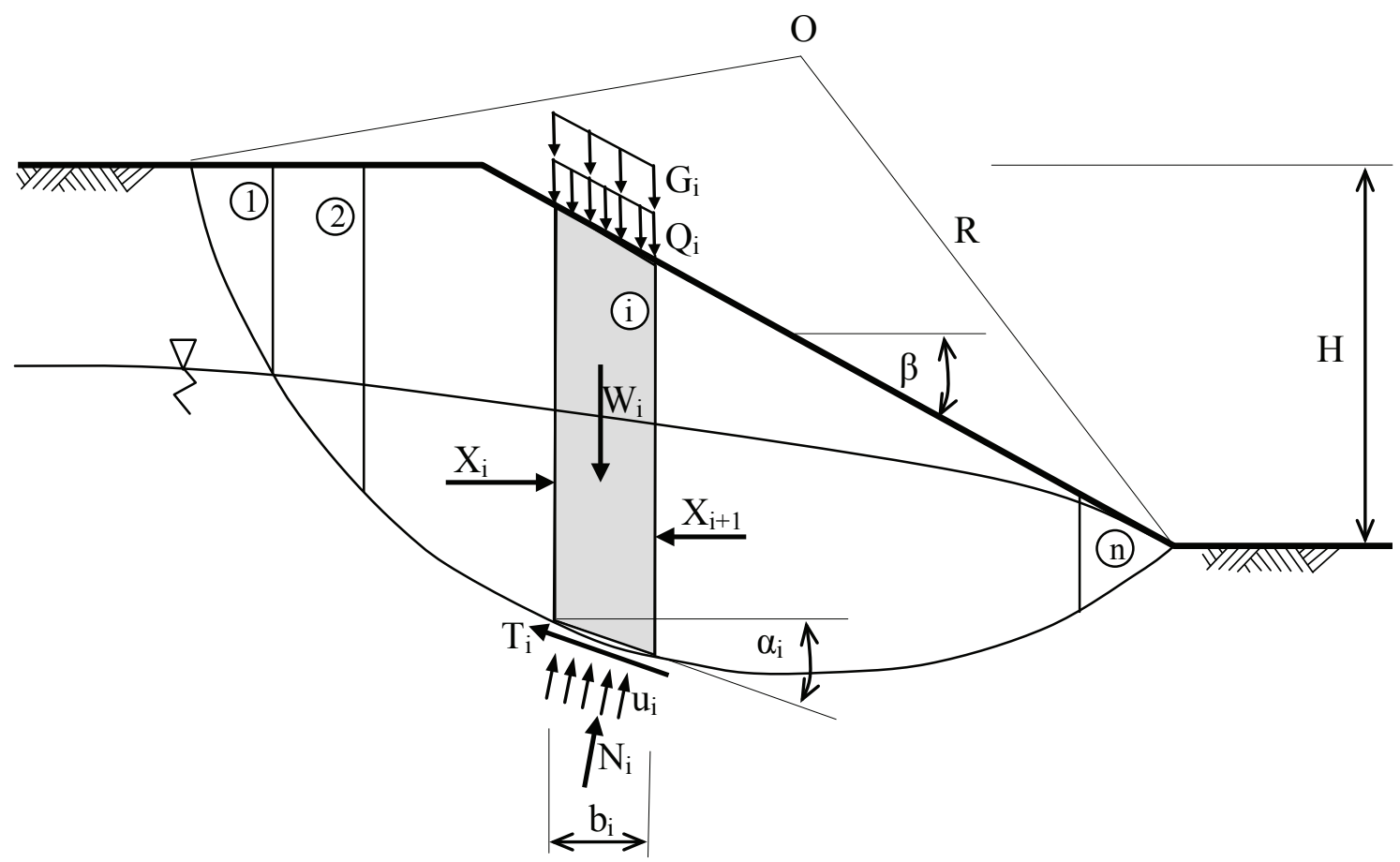

Figure 1: Scheme of the Bishop method (simplified).

Until the moment of the introduction of the National Annex [11] in 2011, which recommends the application of design approach 3 in the case of general stability assessment of slopes, Eurocode 7 did not specify the criteria for the selection of design approaches. Thus, one of three (and in fact four) design approaches that differed in the method of assuming the values of individual partial factors (Table 1) could be used for the stability analysis:

- In the case of design approach 1, combination 1 (DA11), the values of destabilising forces and external loads were increased by multiplying them by the appropriate values of partial factors $\gamma_{G}$ and $\gamma_{Q}$, whilst the values of forces and maintaining impacts were not modified; similarly, the characteristic values of soil strength parameters were also not reduced.

- In the case of design approach 1, combination 2 (DA12), the values of external loads were increased, whilst the values of strength parameters were decreased, reducing them with the use of partial factors $\gamma_{\tan \varphi^{\prime}}$ and $\gamma_{c}$.

- In the case of design approach 2 (DA2), similar to approach 1, combination 1, different partial factors were used for impacts as well as for maintaining and destabilising forces, but the characteristic values of strength parameters were not reduced. Shear resistances on the slip surface were subject to reduction (they were divided by the coefficient $\gamma_{R ; e}$ ).
- Approach 3 (DA3) is very similar to approach 1, combination 2. The only difference is the fact of treating all impacts on the substrate as geotechnical impacts, which results in assuming characteristic values of constant external loads, by applying $\gamma_{G}=1.0$. External variable loads must be multiplied by the factor of $\gamma_{Q}=1.3$.

In the publications [2] and [3], the authors indicated the consequences of selection of individual design approaches, which significantly affected the value of stability coefficient and, in consequence, the assessment of safety of road embankment exploitation.

By recommending the application of approach 3, the National Annex [11] significantly facilitated the performance of general stability analyses of slopes, particularly for persons with less experience. All impacts on the substrate are treated as geotechnical impacts and this results in the use of characteristic values of constant external loads through the adoption of $\gamma_{G}=1.0$. In turn, the external variable loads that affect the landslide solid must be multiplied by the coefficient $\gamma_{Q}=1.3$ and the values of parameters of soil shear strength must be decreased, through reducing them with the use of appropriate values of partial factors $\gamma_{\tan \varphi^{\prime}}$ and $\gamma_{c^{\prime}}$.

As indicated by the results of the assessments for stability presented in the further part of this work, 
Table 1: Values of partial factors recommended for use in the analysis of slope stability

\begin{tabular}{llllll}
\hline \multicolumn{2}{l}{ Partial factors } & \multicolumn{2}{l}{ Design approach } & 2 & 3 \\
& & $\begin{array}{l}1 \\
\text { Combination 1 }\end{array}$ & Combination 2 & & \\
\hline$A \quad$ & $\gamma_{G}$ & 1.35 & 1.0 & 1.35 & $1.0^{*}$ \\
& $\gamma_{G f a v}$ & 1.0 & 1.0 & 1.0 & 1.0 \\
& $\gamma_{Q}$ & 1.5 & 1.3 & 1.5 & $1.3^{*}$ \\
$M$ & $\gamma_{\tan \varphi^{\prime}}$ & 1.0 & 1.25 & 1.0 & 1.25 \\
& $\gamma_{c^{\prime}}$ & 1.0 & 1.25 & 1.0 & 1.25 \\
& $\gamma_{\gamma}$ & 1.0 & 1.0 & 1.0 & 1.0 \\
$R$ & $\gamma_{R ; e}$ & 1.0 & 1.0 & 1.1 & 1.0 \\
\hline
\end{tabular}

*These actions are treated as geotechnical actions.

the selection of approach 3 in many design cases may be debatable, in particularly in conditions of poor recognition of subsoil conditions. One of the arguments for introducing this approach was the ease of application for numerical calculations, particularly in the case of FEM, because of the lack of necessity to use various partial factors for maintaining and destabilising impacts, which occurs in the case of approach 1 , combination 1 , as well as in the case of approach 2.

\section{Discussion on Stability Assessments of Slopes in Case of Communication Embankments (According To Eurocode 7)}

For the discussion concerning the method for the assessment of the stability of slopes in case of road embankments and interpretation of the obtained stability margin, the results of calculations carried out in more than a dozen of cross sections of the embankment along the Bolków ring road have been used. Stability analyses were carried out based on the recommendations given in the Eurocode 7. Selected cross sections were characterised by high variability of foundation conditions. The obtained assessments were referred to the requirements regarding the stability of slopes determined by the existing national regulations [13].

The original $S M B$ programme was applied for stability analyses, which uses the modified Bishop method. The required value of the factor of stability $F_{\text {req }}=1.00$ was adopted as a required value (acceptable) for analyses conducted on the Eurocode 7 basis. The design values of parameters were assumed, which according to Eurocode 7 [9] should provide an adequate margin of stability.

Presented below is the stability assessment of slopes of the road embankments and excavations as well as carrying capacity of the substrate along the Bolków ring road at km $0+000$ to $5+000$, including stability of the body of road designed near the Mining Plant Bolków I. The analysed area is located in the Silesian Lowlands, in the southern part of Lower Silesia Province, within the town and commune of Bolków. The planned Bolków ring road (with the length of $5,538 \mathrm{~km}$ ) will be located along the national roads 3 and 5 . The beginning of the ring road $(\mathrm{km} 0+000)$ is located in the village of Jeżów, northwest of Bolków. Subsequently, the road will run over the inactive railway line (BolkówMieroszów), through flyovers no. 1-E1 and no. 2-E2 through Stare Rochowice, Wierzchosławice, and through overpass no. 3-E3, it will cross the valley of Nysa Szalona. The end of the planned section of the Bolków ring road $(\mathrm{km} 5+$ 538) was designed at the connection with the road no. 5 in the direction of Wrocław. At significant lengths, this ring road will be run on embankments with various heights (approximately 2.0-7.5 $\mathrm{m}$ in the area of flyovers) and in excavation up to a depth of approximately $3.50 \mathrm{~m}$ (from $\mathrm{km}$ $4+100$ to $\mathrm{km} \mathrm{5+050).}$

In general, it is found that geological engineering conditions are complex because of the diversity of layers in terms of their type and condition as well as the occurrence of numerous drainages, which in some sections are intensive (in the region of occurrence of surface watercourses, within gravel layers, at the depth of 1.20-4.90 m below ground level). All groups of substrate carrying capacity, from G1 to G4, occur in the substrate. The following were recognised: silty clays, dusts, sandy dusts, sandy clays, silty clays concise with rock rubble (to a depth of $2.0-4.0 \mathrm{~m}$ below ground level) below the residual clay soils and residual soils. In some test openings, there are cohesive soils in the plastic and soft plastic state. Hydrogeological conditions describe the following levels: free water table in river sediments of the Nysa Szalona valley (at a depth of 0.0-3.0 m below ground level), free table or stretched in gravels, sands and sandy tilled clay (at a depth of 0.0-5.0 m below ground level). In older substrate rocks, there are groundwaters occurring in the slit or slit-porous centre.

The assessment of foundation conditions of the objects of designed Bolków ring road, in the area of mining damages from the Mining Plant Bolków I, showed no occurrence of mining damages in the subject area. 
There is a need to

- protect cohesive soils and residual clay soils from freezing and stabilise the bottom of excavation - with layer of mixtures with a binder (because of the occurrence of groundwater drainages);

- carry out construction works in stages and provide permanent geotechnical supervision, because of the possibility of soil softening.

The grade line of Bolków ring road has a varied progress that affects the stability of slopes of embankments and excavations as well as the carrying capacity of the substrate to a different degree. The grade line runs on intermediate sections (excavation/embankment), embankments with a height of up to $10.5 \mathrm{~m}$ (partial cross section), excavations (service road has an excavation with a depth of approximately $12 \mathrm{~m}$ ) and in the vicinity of exploited clay mine Bolków I. On the basis of analyses of subsoil, grade line progress and other geological conditions, the following cross sections have been identified, which may pose a potential threat in the scope of stability of earth structures designed on the subject ring road.

a) $\mathrm{km} 0+150$ - partial cross section in which part of the embankment is located on a natural slope,

b) $\mathrm{km} 0+796$ - cross section before the flyover no. 2 , embankment with a height of approximately $7.5 \mathrm{~m}$,

c) $\mathrm{km} 1+174$ - cross section after the flyover no. 2, embankment with a height of approximately $7 \mathrm{~m}$,

d) $\mathrm{km} 3+732$ - cross section after the flyover no. 3, embankment with a height of approximately $5 \mathrm{~m}$,

e) $\mathrm{km} 4+900$ - cross section within the clay mine, excavation,

f) $\mathrm{km} 0+105-$ road $08-$ cross section in the excavation.

\section{At km $0+150.02$ of the ring road}

a) Minimum value of the stability factor of the embankment made of non-cohesive soil amounts to $F_{\text {min }}=0.87$ (Figure 2).

b) Minimum value of the stability factor of the embankment made of cohesive soil amounts to $F_{\min }=$ 0.89 (slip line similar to that shown in Figure 2).

c) Value of the stability factor of the embankment, along with the soil, amounts to $F_{\text {min }}=0.88$ (Figure 3).

d) The results of the conducted analyses indicate the instability of embankment made of both non-cohesive and cohesive soil. This is affected by inadequate strength parameters of the substrate and inclination of the slopes of road embankment.

e) In the case of using embankment reinforcement, there is a risk of slipping after contact of the layers. f) After thorough recognition of the substrate (deeper drilling + research), a method of its reinforcement must be proposed, for example, by nailing.

\section{At $\mathrm{km} 0+796.18$ of the ring road (Figure 4)}

a) The minimum value of the stability factor of the embankment made of cohesive soil $\left(y=20.5 \mathrm{kN} / \mathrm{m}^{3}\right.$, $\phi=17^{\circ}, c=22 \mathrm{kPa}$ ) amounts to $F_{\text {min }}=1.17>F_{\text {req }}=1.0$ (Figure 5).

b) The minimum value of the stability factor of the embankment made of non-cohesive soil amounts to $F_{\text {min }}=1.03>F_{\text {req }}=1.0$ - this value is ensured in the case of the following embankment soil parameters: $\phi \geq$ $33.6^{\circ}, c \geq 2.5 \mathrm{kPa}$.

c) In the case of using non-cohesive soil, it is recommended to reinforce the embankment with geogrids with a length of $\mathrm{L}=7.0 \mathrm{~m}$ and a vertical spacing of $0.5 \mathrm{~m}$ (long-term tensile strength $F_{d} \geq 13$ $\mathrm{kN} / \mathrm{m}$ ) on the length in the range of change in the embankment height of 7.5-5.0 m.

\section{At $\mathrm{km} 1+174.22$ of the ring road}

a) The assessment of stability of the embankment made of cohesive soil indicated that it is stable $\left(F_{\min }=1.25\right.$ $>1.0)$.

b) However, there is a problem because of the occurrence of the first layer of clay in the plastic state (Figure 6).

c) Calculations indicated the loss of stability: $F_{\text {min }}=0.73$ $<1.0$ - the potential mechanism of the loss of stability is illustrated in Figure7.

d) This C3 layer should be trenched up to hard plastic clays. Strengthening of the substrate with a stone mattress wrapped in geogrids may lead to the squeezing of plastic clays into the trench located on the right side.

The subject of separate analyses of the authors is also the stability assessment of the road body near the mine Bolków I - conducted using FEM in GEO5 programme in order to forecast the size of the substrate displacements.

a) Calculations for the slope stability of excavations apply to $\mathrm{km} 4+400$ (there are semi-compact soils and soft rock); $\mathrm{km} 4+900$ (there are cohesive soils alternately in the hard plastic and plastic state, whilst below there is residual soil and soft rock); and $\mathrm{km} 4$ + 982 (there are semi-compact and hard plastic soils).

b) The results from the calculation concerning the minimum value of the stability factor of the excavation slopes (of upper part of the slope above the excavation and lower part of the slope below the road excavation) 

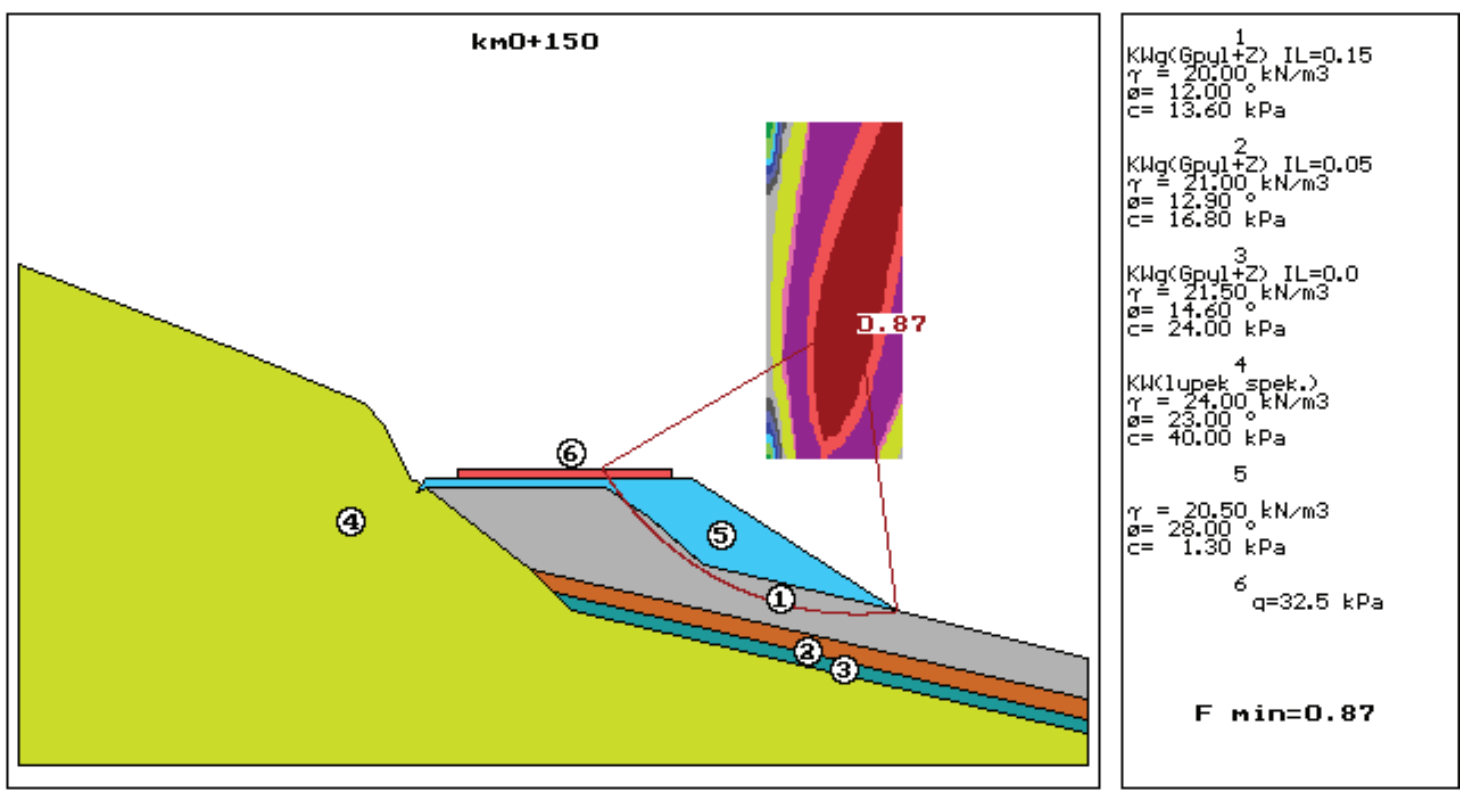

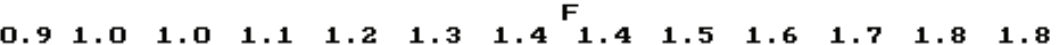

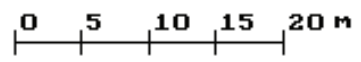

Figure 2: Bolków ring road, cross section of km $0+150.02$ : stability according to EC7 of embankment made of non-cohesive soil.
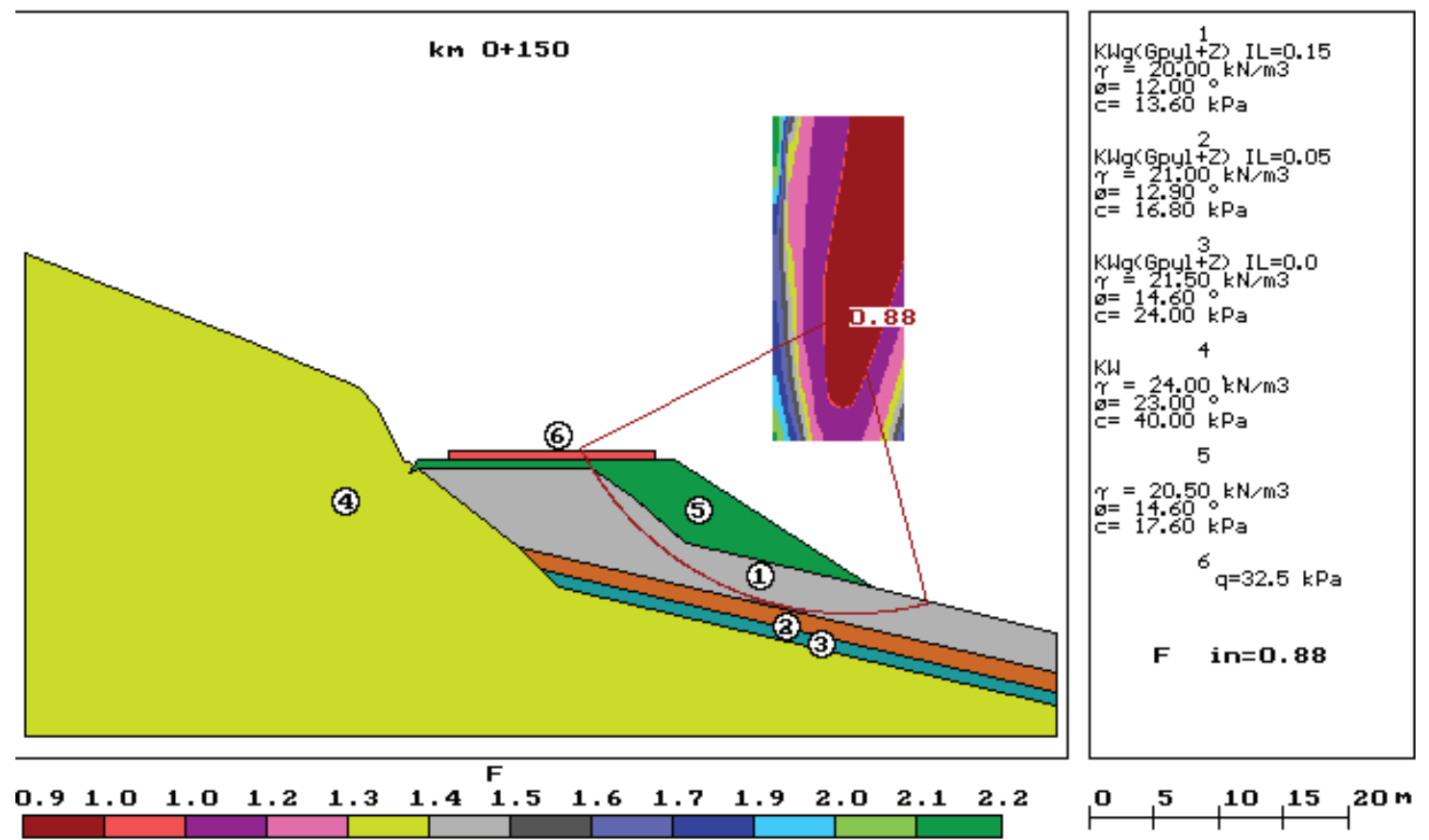

Figure 3: Bolków ring road, cross section of $\mathrm{km} 0+150.02$ : stability according to EC7 of embankment made of cohesive soil, along with the substrate 


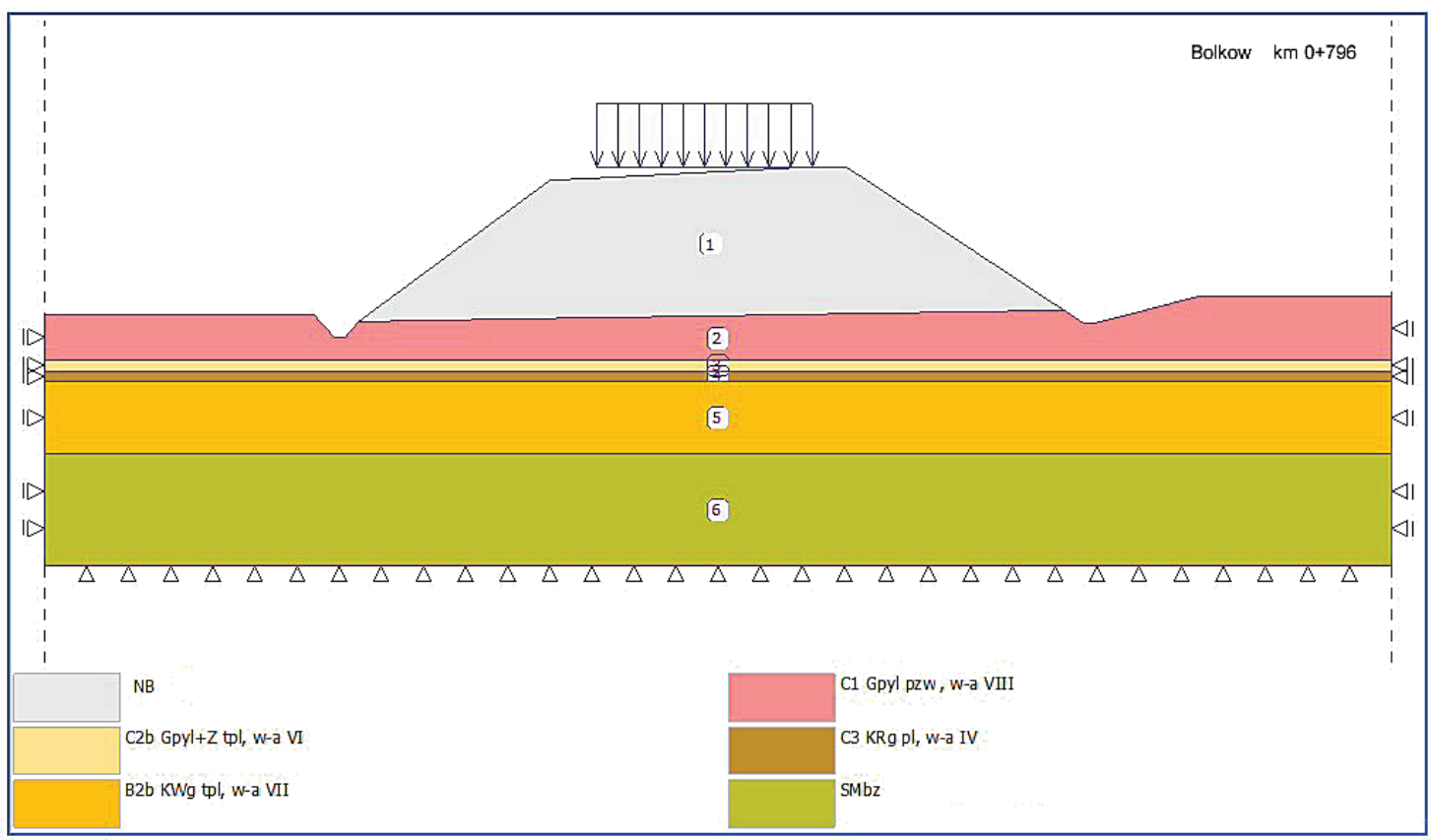

Figure 4: Cross section of $\mathrm{km} 0+796.18$ - computational scheme.

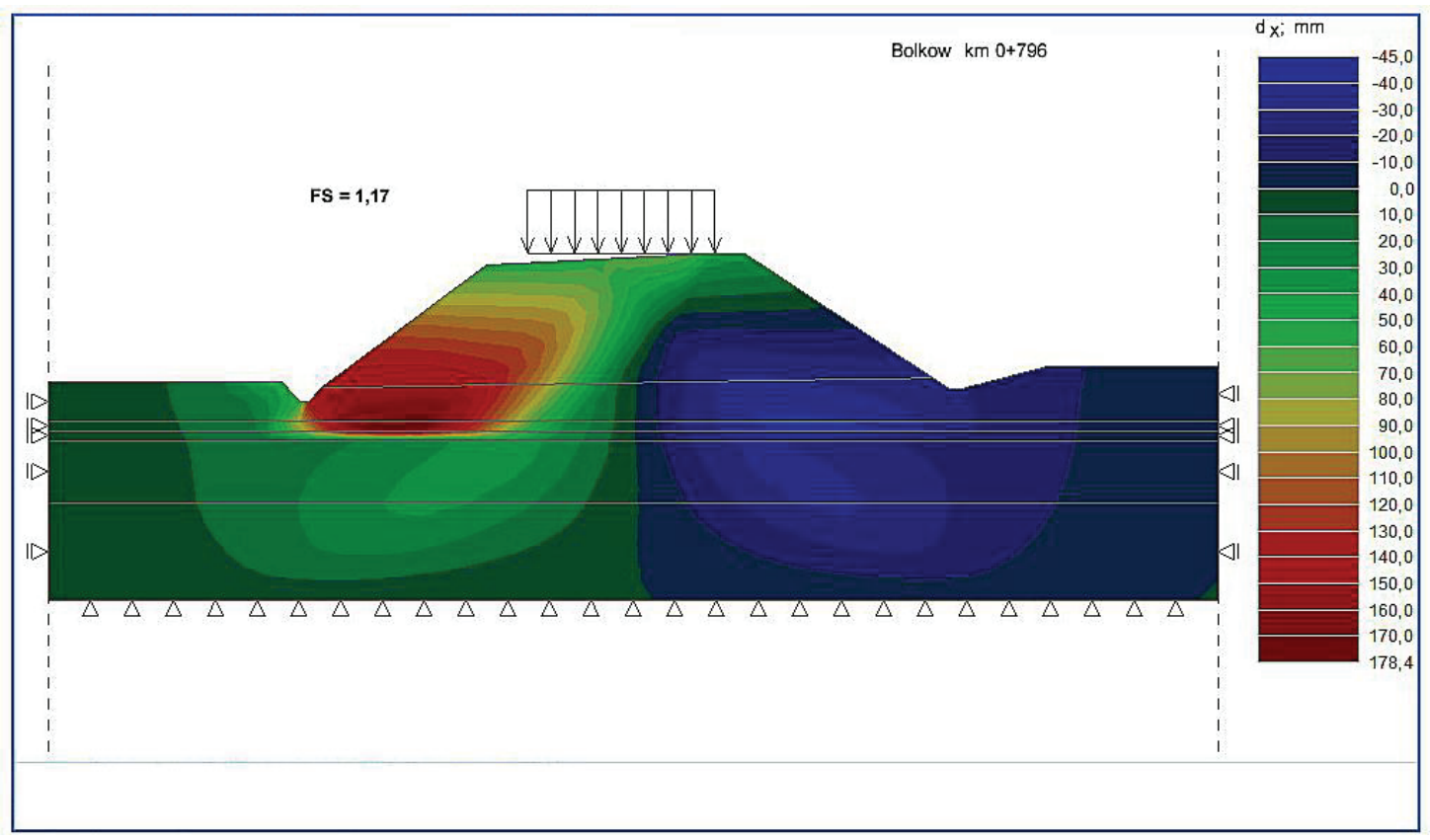

Figure 5: Cross section of $\mathrm{km} 0+796.18$ - stability calculations (distribution of displacements) of the embankment made of cohesive soilg $=$ $20.5 \mathrm{kN} / \mathrm{m}^{3}, \phi=17^{\circ}, c=22 \mathrm{kPa}$, according to Eurocode $7\left(F_{\min }=1.17>F_{\text {req }}=1.0\right)$ 


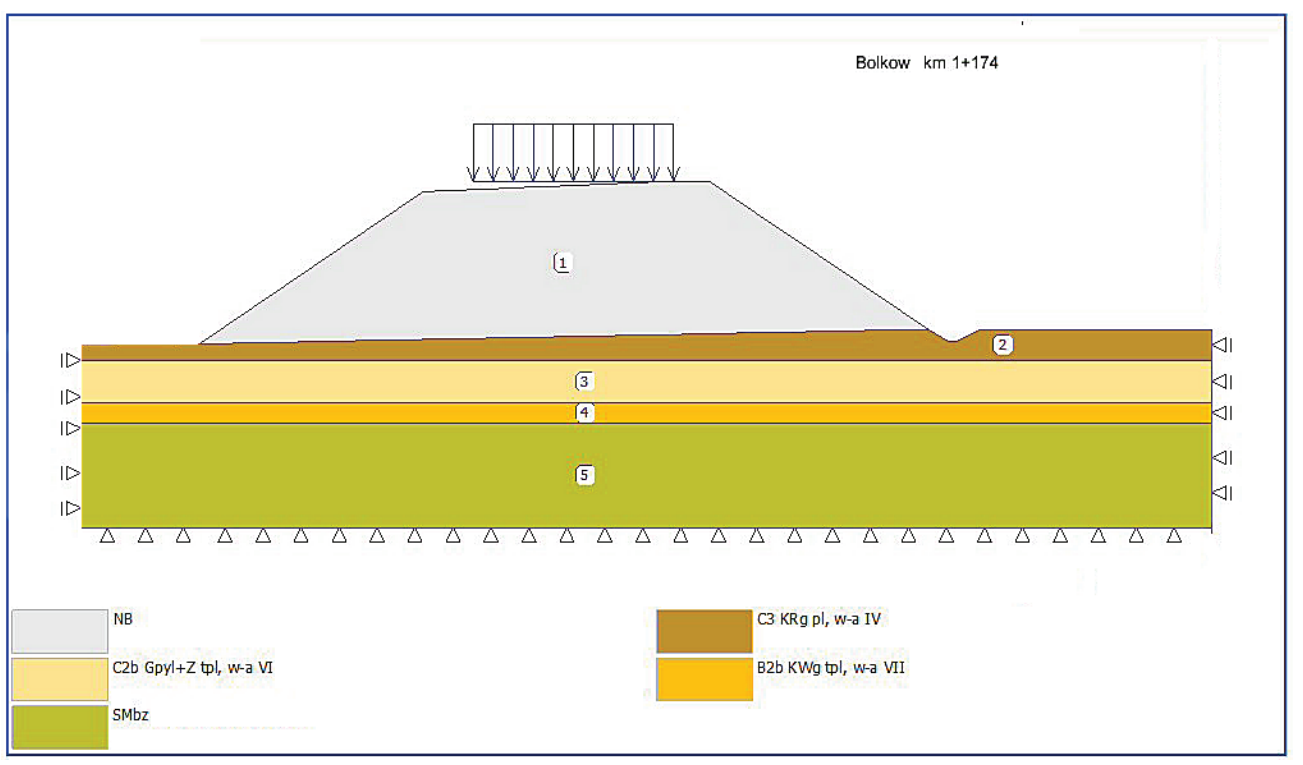

Figure 6: Computational scheme.

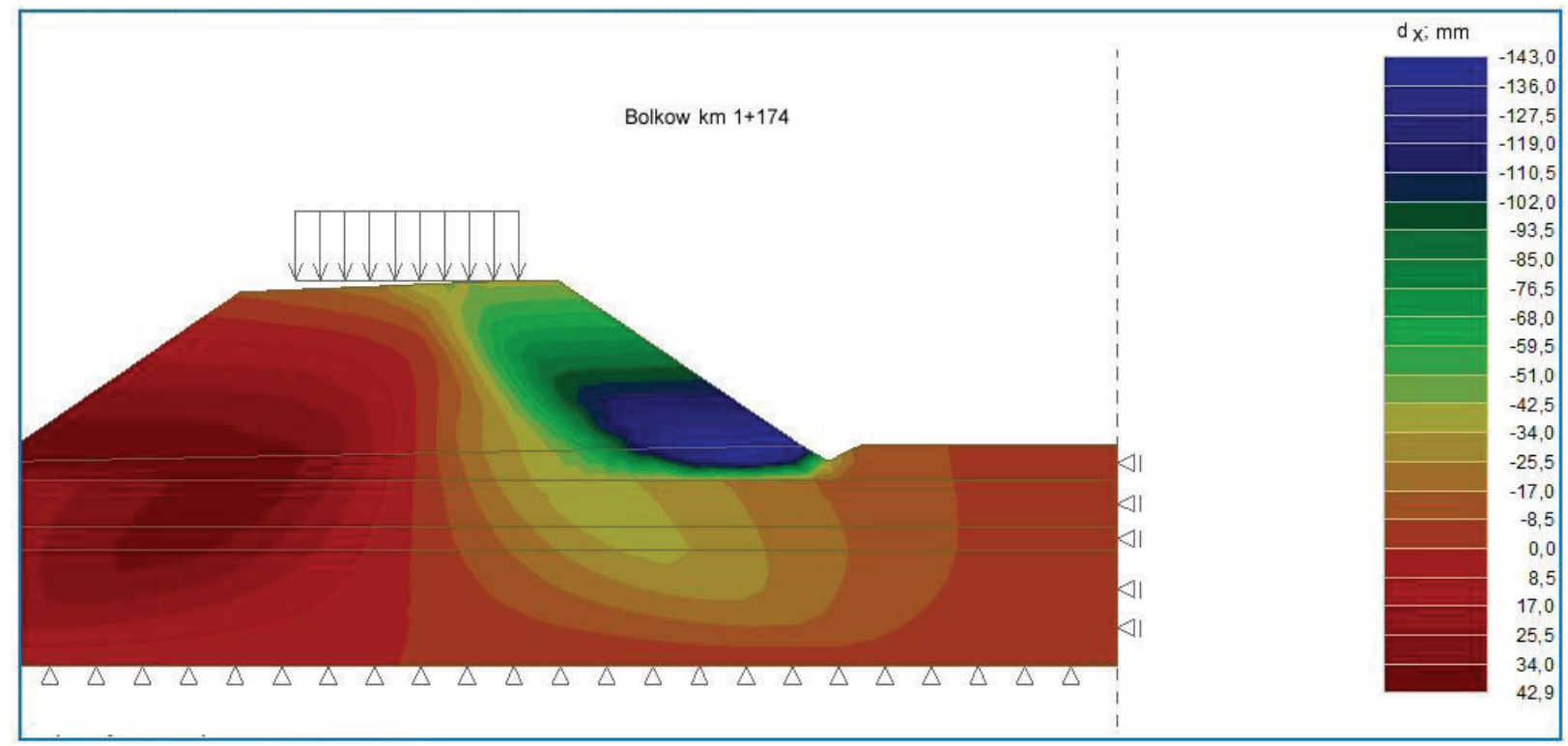

Figure 7: Potential mechanism of the loss of stability - green-blue block in the right slope..

are presented, for example, at $\mathrm{km} 4+900.00-$ it is the most unfortunate case of excavation, because of its depth and substrate layering.

c) At km 4+900.00 of the road (Figure 8-11): Upper part of the slope above the road excavation, $F_{\text {min }}=1.88$;

Lower part of the slope below the road excavation, $F_{\text {min }}=2.01$;
Horizontal and vertical displacements are smaller than maximally allowed.

The subject of analyses also includes the assessment of stability of road 08 slope of the Bolków ring road at km $\underline{0+105.00}$ (Figure 12-14), with the following values of characteristic parameters: 


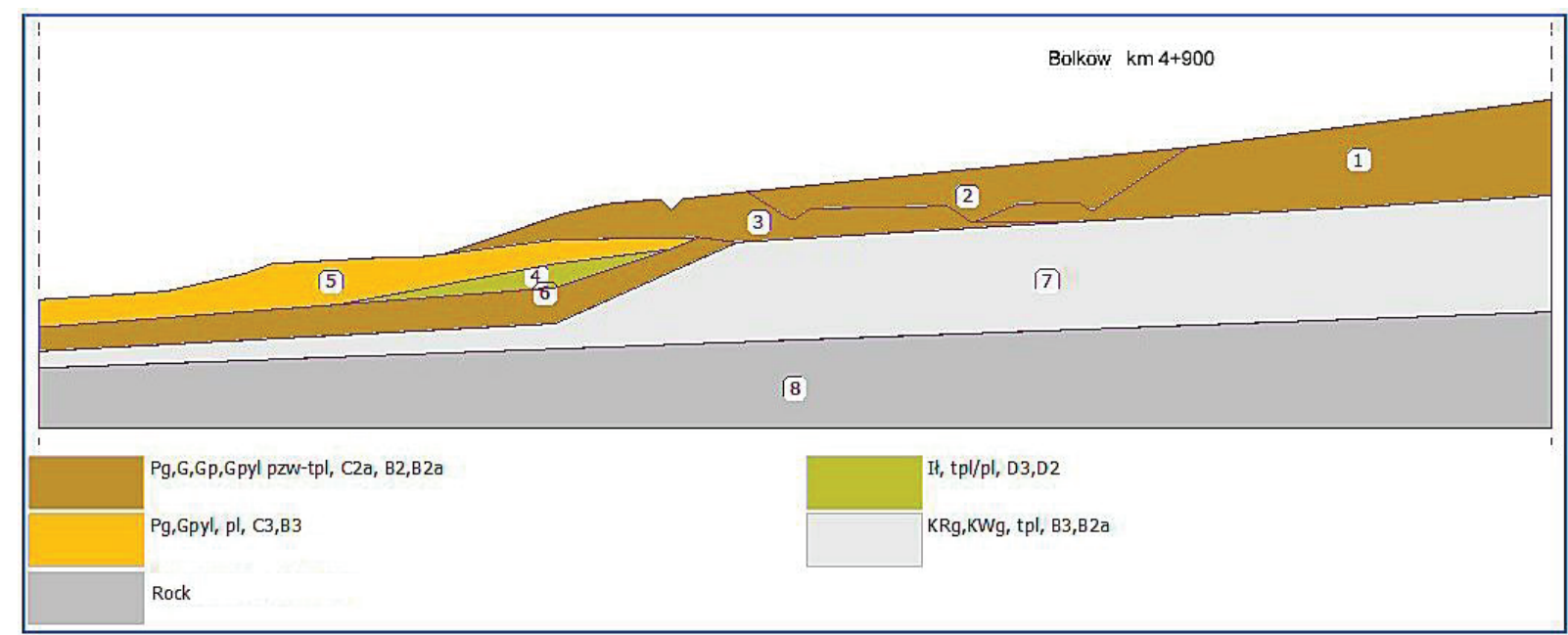

Figure 8: System of ground layers. Phase 1 of calculations - state before performance of a road excavation.

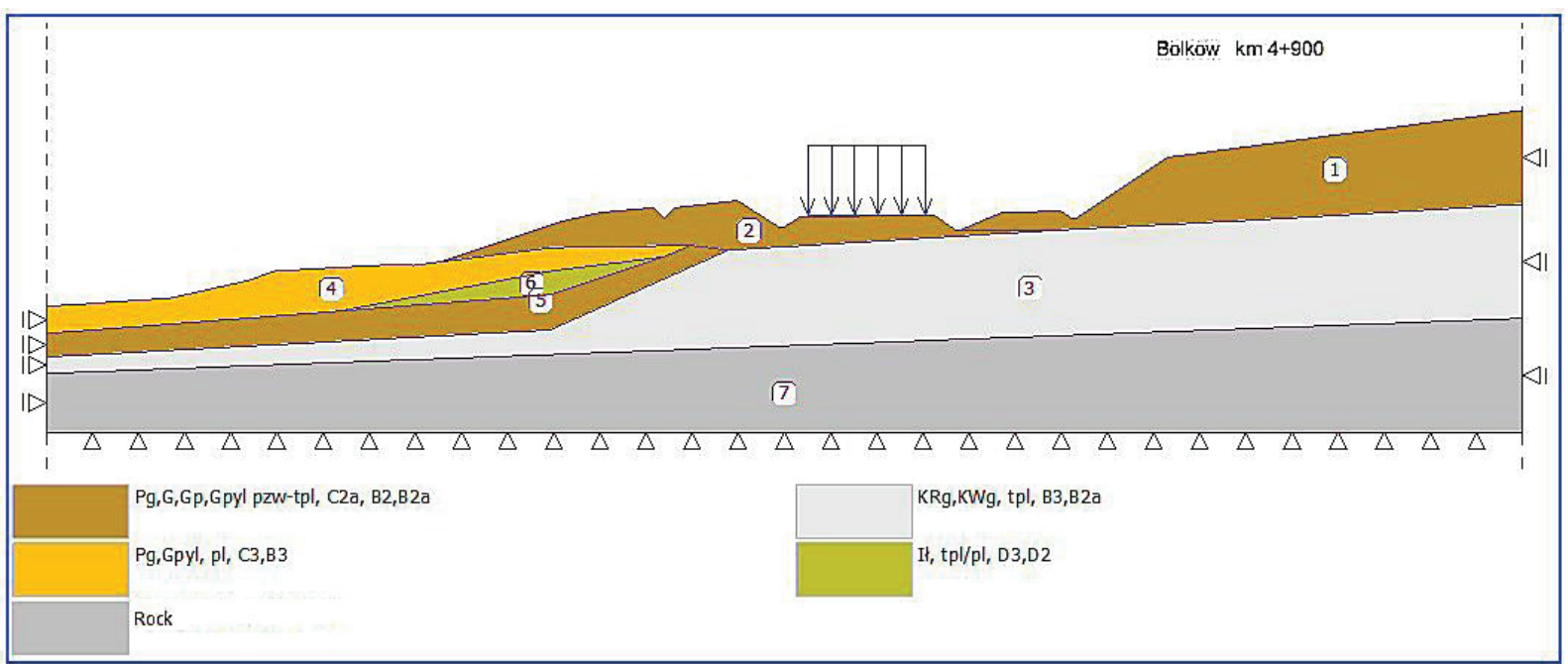

Figure 9: System of ground layers. Phase 2 of calculations - state with road load after the performance of a road excavation

KR brown humid rock debris $-g=19.5 \mathrm{kN} / \mathrm{m}^{3}, \phi=31^{\circ}$,

$$
c=3 \mathrm{kPa}, E=11 \mathrm{MPa} \text {; }
$$

KW not very humid brown weathered rock $-\mathrm{g}=$ $21.0 \mathrm{kN} / \mathrm{m}^{3}, \phi=36^{\circ}, c=3 \mathrm{kPa}, E=25 \mathrm{MPa}$;

KW rock (cracked) - brown dry green area $-g=$ $24.0 \mathrm{kN} / \mathrm{m}^{3}, \phi=38^{\circ}, c=10 \mathrm{kPa}, E=120 \mathrm{MPa}$.

The minimum value of the stability factor of the embankment amounts to $F_{\min }=1.40>F_{\text {req }}=1.0$ (Figure 14).

\section{Summary of Analyses}

Results of the stability assessment of slopes in case of the ring road embankments are diversified and mainly depend on their height as well as carrying capacity of the substrate.

- At km $0+150.02$, the instability was found in regard to the embankment made both of non-cohesive and cohesive soil $\left(F_{\min }=0.88\right)$. This results from insufficient strength parameters of the substrate. In the case of using embankment reinforcement, there is a risk of slipping after contact of the layers. After thorough 


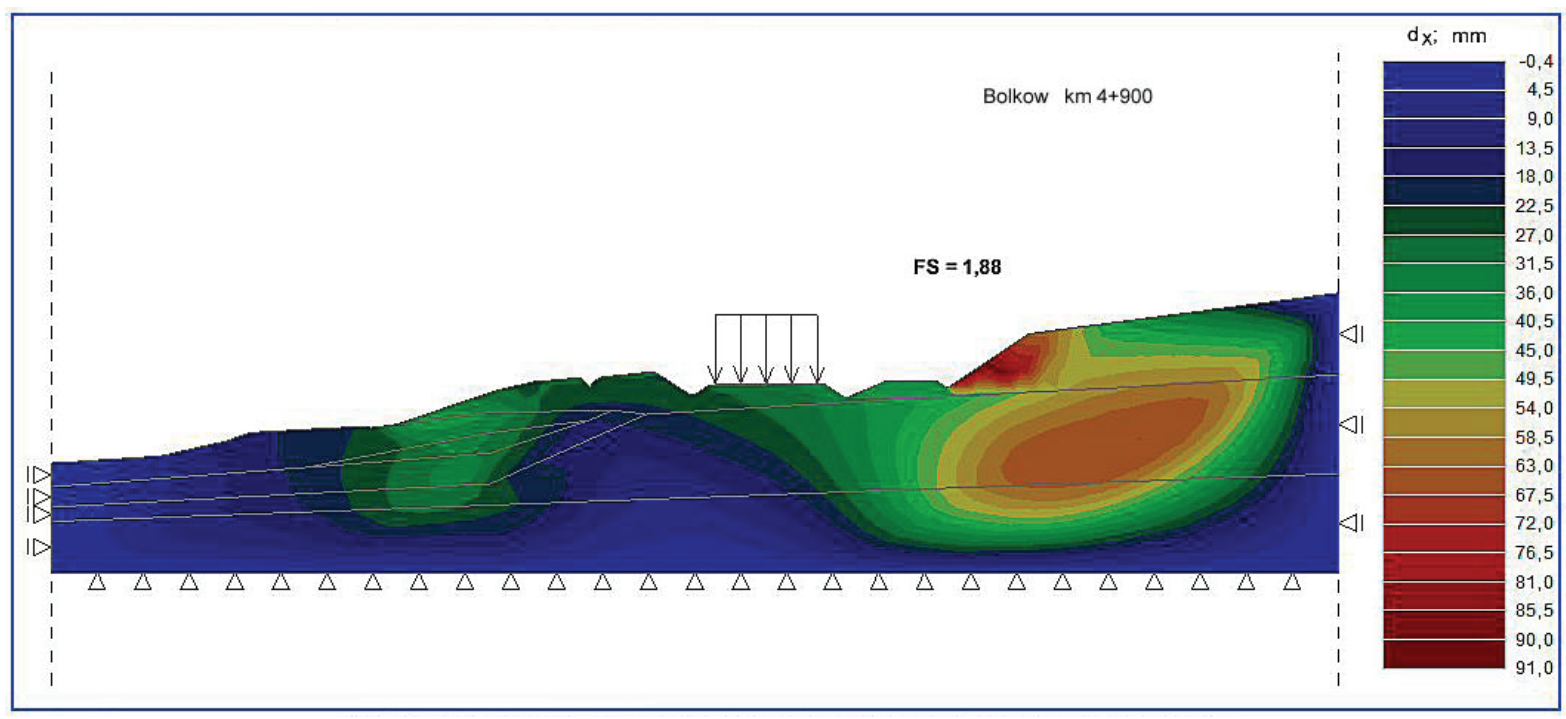

Figure 10: Phase 2 of calculations - stability analysis of the upper part of the slope above the road excavation, $F_{\min }=1.88$.

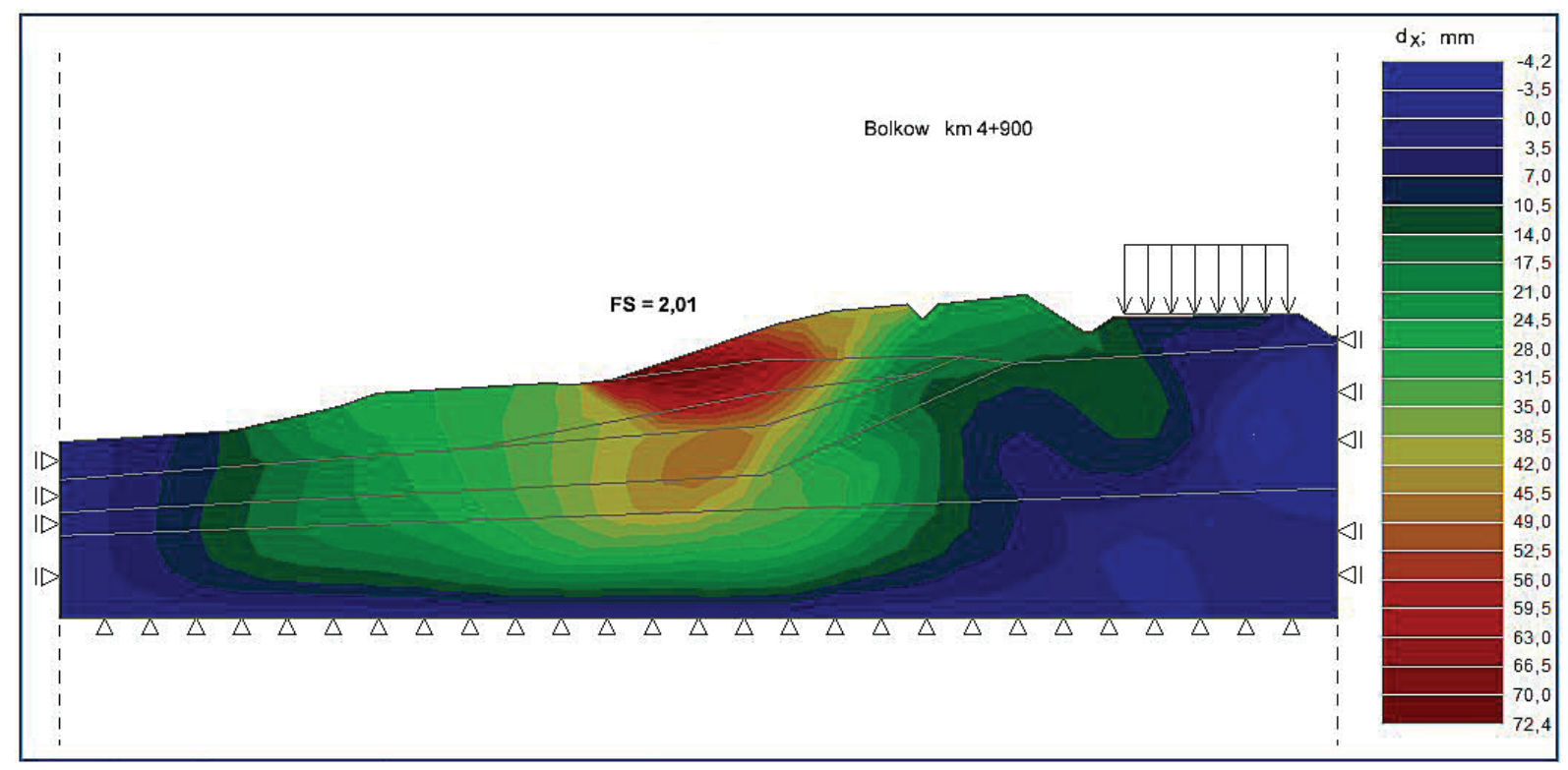

Figure 11: Phase 2 calculations - stability analysis of lower part of the slope below the road excavation $F_{\min }=2.01$.

recognition of the substrate, a method of its reinforcement must be proposed, for example, by nailing.

- At km $0+796.18$, the condition of stability of the embankment settled on the supporting substrate is met, provided that the appropriate soil for the embankment body construction is adopted:

a) in the case of embankment made of cohesive soil ( $y=$ $\left.20.5 \mathrm{kN} / \mathrm{m}^{3}, \phi=17^{\circ}, c=22 \mathrm{kPa}\right) F_{\text {min }}=1.17>F_{\text {req }}=1.0$;

b) in the case of embankment made of non-cohesive soil, the value $F_{\text {min }}=1.03>F_{\text {req }}=1.0$ is ensured with the following parameters of embankment soil: $\phi \geq 33.6^{\circ}$, $c \geq 2.5 \mathrm{kPa}$;

c) in the case of using non-cohesive soil, it will be necessary to reinforce the embankment with the use of geogrids with the technical parameters specified above.

- At km 1+174.22,

a) embankment made of cohesive soil $\left(y=20.5 \mathrm{kN} / \mathrm{m}^{3}, \phi\right.$ $=17^{\circ}, c=22 \mathrm{kPa}$ ) meets the required stability margin $\left(F_{\text {min }}=1.25>1.0\right)$; 


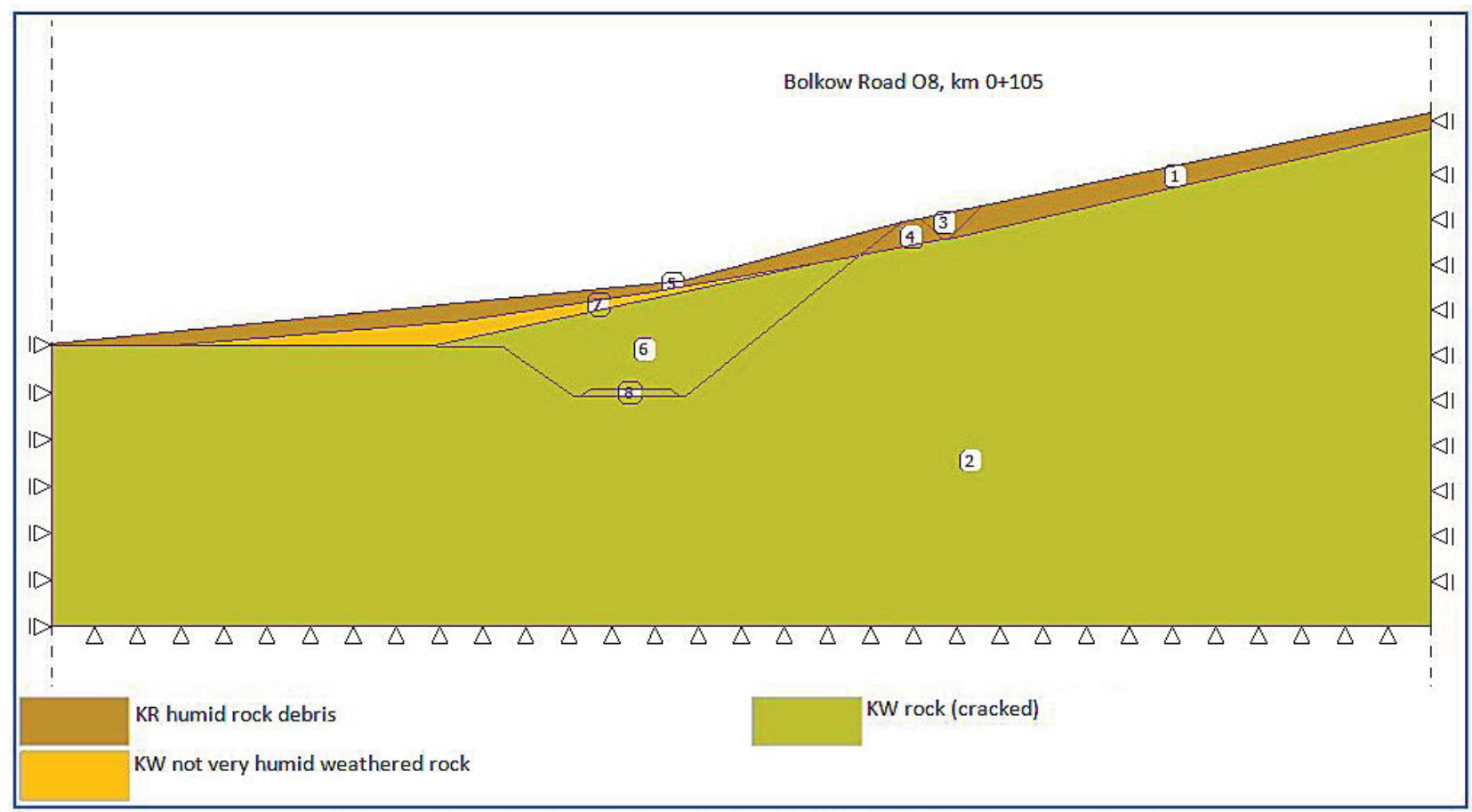

Figure 12: Current profile of the road 08 slope at $\mathrm{km} 0+105.00$.

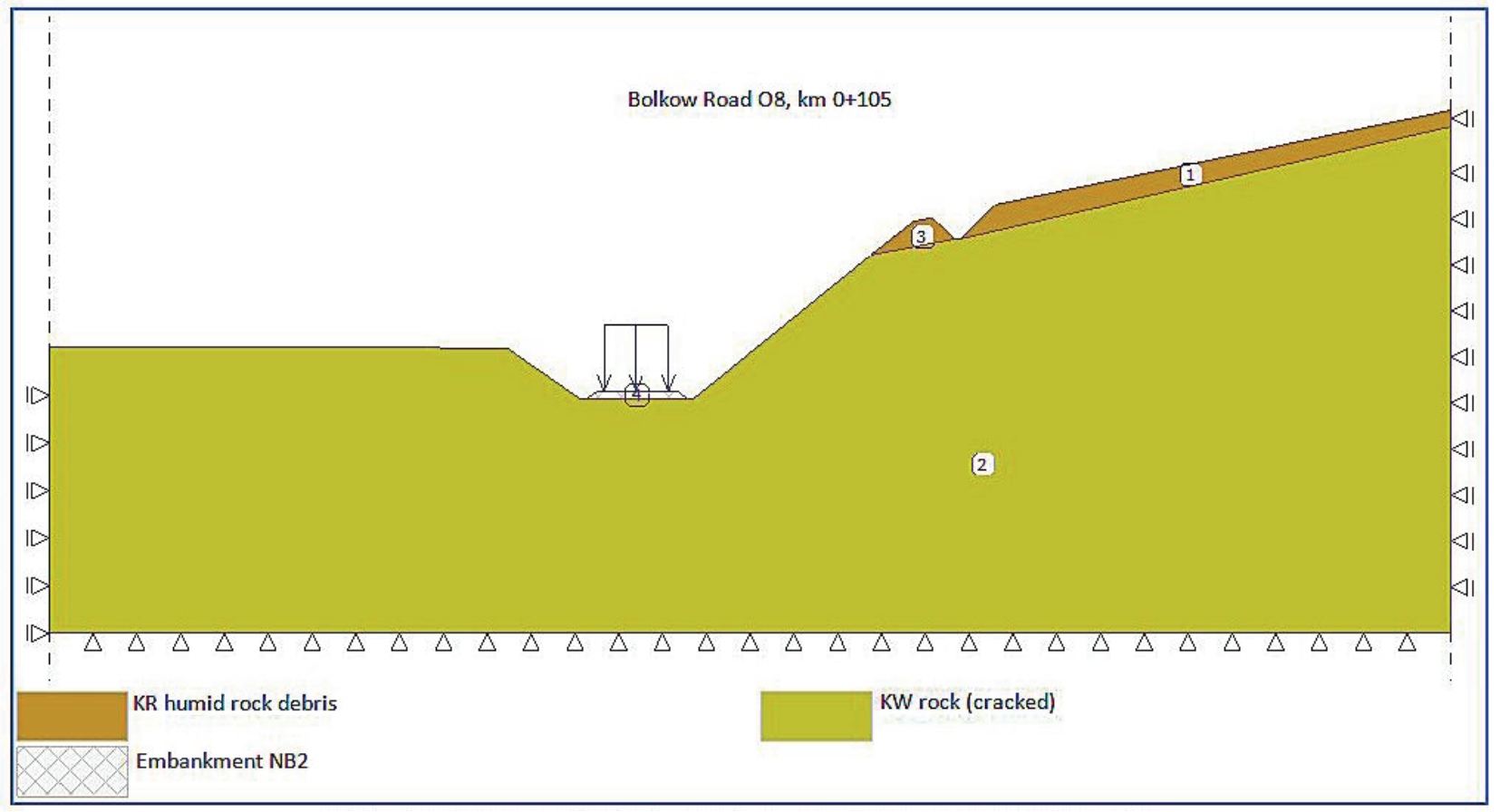

Figure 13: Designed slope profile of the road 08 excavation in the cross section of $\mathrm{km} 0+105.00$ 


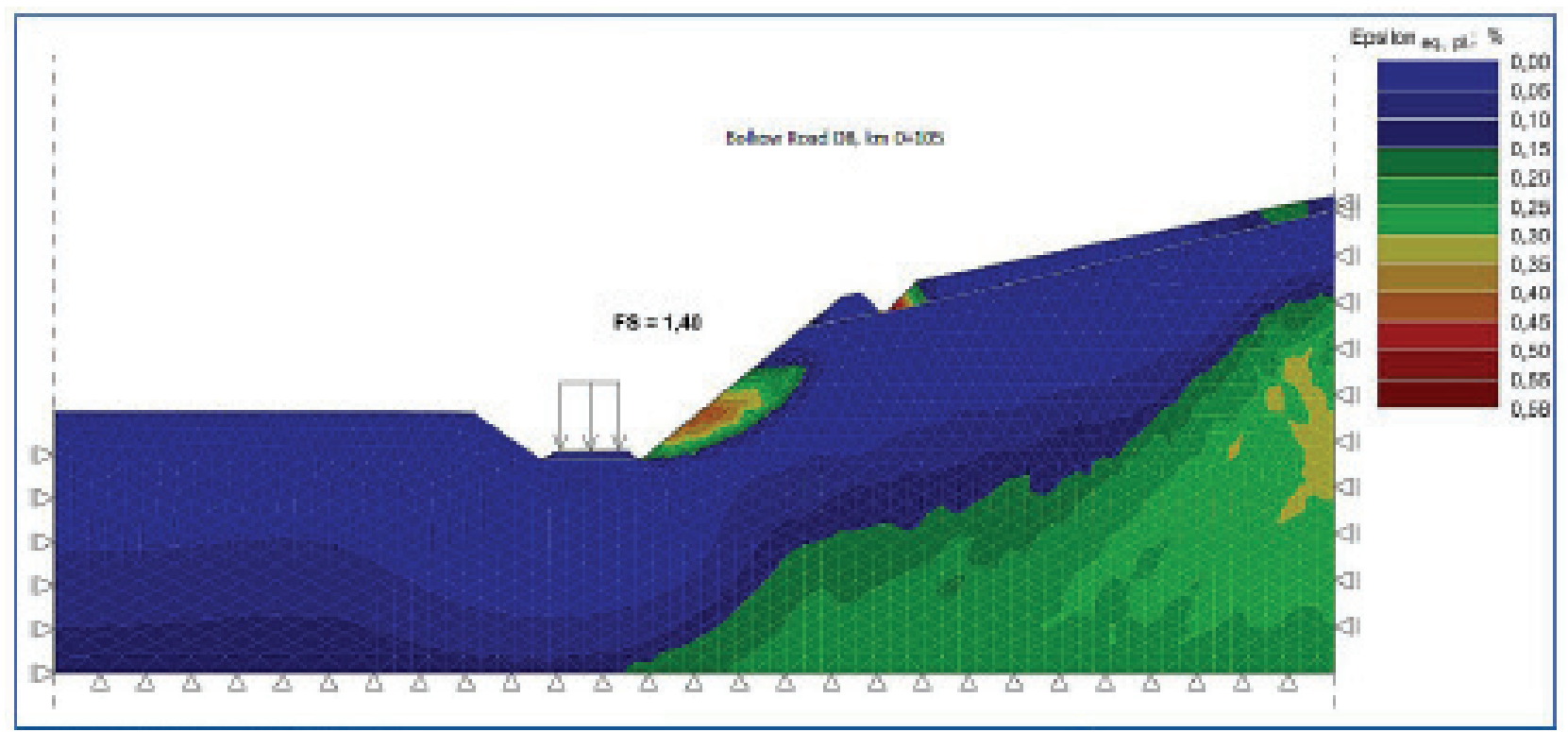

Figure 14: Results of stability calculations of the slope $F_{\min }=1.40$.

b) in the case of using non-cohesive soil $\left(\phi \geq 33.6^{\circ}, c \geq 2.5\right.$ $\mathrm{kPa}$ ), the embankment should be reinforced with the use of geogrids. Substrate in the place of foundation of the earth structure is weak;

c) the occurrence of an irrigated layer of clay in a plastic state in one of the test openings indicates a potential mechanism of the loss of stability $\left(F_{\min }=0.73<1.0\right)$. This layer should be trenched (with the thickness of $1.0 \mathrm{~m}$ ) up to hard plastic clays (up to a depth of 1.5 $\mathrm{m}$ below ground level). Enforcing the substrate with a stone mattress wrapped in geogrids can lead to squeezing the plastic clays into the ditch located on the right side.

- At km 0 + 105.00 of the road 08 of the Bolków ring road, it is necessary to ensure the detailed recognition of the geological structure of the rock slope. The assessment of stability of the cover layers (debris, residual soil) in the highest part of the slope, with the values of characteristic parameters adopted by the authors - resulted in the minimum value of stability factor of the embankment $\left(F_{\text {min }}=1.40>F_{\text {req }}=1.0\right)$.

\section{Final Conclusions}

1. Assessment of stability of the slopes and slopes in road construction is one of the main issues in the process of design, which ensures the safety of the road use. The stability factor F (or factor of safety [FOS]), applied as the basic parameter for the assessment of the stability margin, can take different values depending on the method used for the calculation and the approach adopted for the calculation.

2. Guide ITB no. 424/2011 [12] provides, amongst others, that safe values of the equilibrium indicator at medium parameters should assume values not lower than $\mathrm{F}=1.3$.

3. Requirements of the German standard DIN 4084:1981 are similar and they recommend the adoption of a safety coefficient (in the case of a parallel landslip to the slope surface) depending on the load system from 1.3 (basic load system) to 1.1 (emergency state, impacts of seismic loads). In the case of high soil cohesion (c > $20 \mathrm{kPa}$ ), $\mathrm{F}=1.73$ to 1.47 are appropriately used. Newer issue of the standard E DIN 4084: 2002, adapted to ENV version of the Eurocode, for three load systems provides the following values: $\mathrm{F}=1.25,1.15$ and 1.1.

4. The authors demonstrated that individual approaches of stability assessment of the slopes, introduced by Eurocode 7 [9], are not equivalent and the indication in the National Annex [11] of the calculation approach 3 for stability assessment requires a good recognition of geotechnical conditions - responsible for the preparation of the geotechnical studies programme of the designed investment.

5. For the purposes of stability analysis of slopes conducted according to Eurocode 7 in Poland, it is recommended to apply calculation approach 3, in which partial factors are only used to soil strength 
parameters and variable loads. It should be noted that the stability margin values provided in this manner are generally smaller than the value that was obligatorily required until recently in the Regulation MTiGM [13]. Only the calculation approach 2, according to Eurocode 7, enabled to obtain a comparable stability margin. The value of stability factor $F=1.50$, which was obligatorily required until recently for road embankments, was widely criticised (see [5]), which in the case of slopes in simple ground conditions was justified. In 2016, a recommendation was introduced in the subject regulation [13] for conducting stability assessments of road embankments, according to Eurocode 7 (approach 3), and according to the authors, it allows to ensure the optimal level of stability margin for simple ground conditions. However, it seems necessary to be very careful during stability calculations with the use of approach 3 in the cases of poor recognition of substrate conditions, with high variability of soils occurring in the analysed ground massif or with the occurrence of uncontrolled embankments and organic soils.

6. Selectively demonstrated problems associated with the foundation of transport infrastructure object indicate that the construction of the road network poses many problems because of the linear character of these structures. However, it should be stated that in the scope of subsoil recognition studies, apparatus and equipment that provides a good recognition of the subsoil both in situ and in laboratory conditions are available in the country. In the scope of recognition of the subsoil in the laboratory conditions, it will be necessary to implement the procedures for assessing ground frost resistance with the use of CBR tests.

7. There seems to be an urgent need to undertake works aimed at developing detailed recommendations concerning methods and algorithms for assessing the stability of embankment slopes and road excavations, based on the recommendations of Eurocode 7, taking into account the specificity of ground conditions, as well as conditions for the exploitation of earth road structures. The examples presented in the work indicate problems occurring in the analysis of stability of road embankments performed in complex and complicated ground conditions. Particularly, this applies to the cases in which it is necessary to use geosynthetics in order to ensure the required stability margin. For such situations, the recommendations included in the EBGEO project guidelines can be a good starting point [14].

\section{References}

[1] BATOG A., STILGER-SZYD ŁO E., New approach to assessment of road embankment stability. StudiaGeotechnica et Mechanica, Vol. XXXI, No. 3, 2009.

[2] BATOG A., STILGER-SZYDŁO E., Stateczność skarp nasypów drogowych w ujęciu Eurokodu 7. Drogownictwo 2010, nr 1, s. 18-21.

[3] BATOG A., STILGER-SZYDŁO E., Stateczność skarp nasypów modernizowanej drogi ekspresowej S-8 w ujęciu Eurokodu 7 i aktualnych przepisów krajowych. Drogownictwo 2010, nr 2, s. 39-44.

[4] BISHOP A. W., The use of the slip circle in the stability analysis of slopes, Geotechnique, 1955, no 5, pp. 7-17.

[5] KŁOSIŃSKI B., O wymaganiach dotyczących stateczności skarp i zboczy, Zeszyty Naukowo-Techniczne SITK Oddział Kraków, Problematyka osuwisk w budownictwie komunikacyjnym, seria Materiały Konferencyjne, Nr 88, Zeszyt 144, Kraków 2009.

[6] SIMPSON B., DRISCOLL R., Eurocode 7 a commentary. CRC Ltd., London, 1998.

[7] STILGER-SZYDŁO E., Posadowienia budowli infrastruktury transportu lądowego. Teoria - Projektowanie - Realizacja. Wrocław, DolnośląskieWydawnictwoEdukacyjne, 2005.

[8] WIŁUN Z., Zarys geotechniki, Wyd. KomunikacjiiŁączności, Warszawa 2013.

[9] EN 1997-1:2004 Eurocode 7. Geotechnical design. Part 1. General rules.

[10] EN 1997-2 :2007 Eurocode 7. Geotechnical design. Part 2. Groundinvestigation and testing.

[11] EN 1997-1:2004 Eurocode 7. Geotechnical design. Part 1. General rules. Polish National Annex to Eurocode 7

[12] Poradnik ITB nr 424. Ocena stateczności skarp i zboczy. Warszawa 2011.

[13] Rozporządzenie Ministra Transportu i Gospodarki Morskiej w sprawie warunków technicznych, jakim powinny odpowiadać drogi publiczne i ich usytuowanie. Dz. U. Nr 43/1999 r.

[14] EBGEO: Recommendations for Design and Analysis of Earth Structures using Geosynthetic Reinforcements, Ernst W. \&SohnVerlag 2011. 